\title{
Cytopathic effect of Haemophilus ducreyi for human foreskin cell culture
}

\author{
M. J. ALFA \\ Department of Medical Microbiology, University of Manitoba and St Boniface General Hospital Research Centre, \\ 409 Tache Avenue, Winnipeg, Manitoba R2H 2A6, Canada
}

\begin{abstract}
Summary. An explant adult foreskin cell culture (FS2-3) was compared with human lung carcinoma cell culture (A549) with regard to the ability of Haemophilus ducreyi to produce a cytopathic effect. The survival of $H$. ducreyi for up to 26 days in FS2-3 cells was far greater than in any previously described in-vitro culture system. $H$. ducreyi survived for up to 7 days in A549 cells. The $H$. ducreyi cells grew and formed "fungal-like" microcolonies on the eukaryotic monolayer. Portions of the microcolonies remained attached despite extensive washing. Transmission electronmicroscopy indicated that, at $48 \mathrm{~h}$ after infection, the $H$. ducreyi cells did not penetrate the FS2-3 cells but they were closely associated with them; there was only a 2-5 nm gap between the $H$. ducreyi cell wall and the FS2-3 membrane. The virulent $H$. ducreyi strains RO18 and 35000 produced a cytopathic effect on FS2-3 cells that did not appear to be due to a soluble toxin. These strains did not produce any CPE on A549 cells. $H$. influenzae and the avirulent $H$. ducreyi strain CIP542, inoculated in the same concentration and incubated for the same length of time, did not produce CPE on FS2-3 cells. This study demonstrated that the use of FS2-3 foreskin cell culture provided an in-vitro approach for evaluating the cytopathic effect of virulent $H$. ducreyi whereby, unlike in other in-vitro systems, viability of the micro-organism could be readily maintained.
\end{abstract}

\section{Introduction}

Haemophilus ducreyi is the causal agent of chancroid. Although $H$. ducreyi was described over 100 years ago, little is known about its pathogenicity. Clinically, chancroid is characterised by a genital ulcer that, if untreated, can result in inguinal lymph node involvement, leading to bubo formation and suppuration. As reviewed by Albritton, ${ }^{1}$ it is assumed that $H$. ducreyi gains entry through breaks in the epithelial layer, but nothing is known about its attachment or localisation mechanisms or the cytopathic capacity that ultimately leads to ulcer formation. A rabbit model for chancroid was introduced by Reenstierna, ${ }^{2}$ but in this system, a large inoculum of $10^{8}$ organisms ${ }^{3,4}$ was required to produce a lesion and reproducibility was frequently a problem. Heat-killed $H$. ducreyi did not produce lesions in rabbits. ${ }^{3}$ With this model, avirulent strains CIP542 and A77 have been recognised. ${ }^{4}$ Recently, a CBA mouse model was described by Tuffrey et al., ${ }^{5}$ in which ulcers similar to those observed in man were produced consistently, although, again, the inoculum required was large $\left(10^{7}\right.$ organisms). Both heat-killed and viable organisms could produce ulcers. Histology of these lesions indicated that the characteristic histology of chancroid that was observed in $\operatorname{man}^{6}$ was also apparent in the

Received 26 March 1991; revised version accepted 4 Sept. 1991. mouse lesions. ${ }^{7} H$. ducreyi does not survive for long in either the rabbit or the mouse model and the lesions heal spontaneously., ${ }^{4,5}$ Neither of these animal models was designed for attachment or cytotoxic studies. There have been no published descriptions of cell-culture models for $H$. ducreyi infection.

The primary aim of this study was to determine whether $H$. ducreyi could grow in human lung carcinoma (A549) or adult foreskin explant (FS2-3) cell cultures and to determine whether any specific cytopathic effect was produced in either system.

\section{Materials and methods}

\section{Bacterial strains}

All Haemophilus isolates were maintained as frozen stocks at $-70^{\circ} \mathrm{C}$ in skimmed milk and all subcultures were on chocolate agar incubated at $35^{\circ} \mathrm{C}$ in $\mathrm{CO}_{2}$ $5 \%$ :air $95 \%$ with high humidity. The test strains included $H$. influenzae type b ATCC 10211 and $H$. ducreyi clinical isolates 35000 (Winnipeg strain), RO18, RO27 (Kenyan strains) and CIP542 (Institut Pasteur).

\section{Cell culture}

The eukaryotic cell cultures evaluated were A549-a transformed cell line derived from a human lung 
carcinoma (ATCC CCL21) - and FS2-3-a primary, non-transformed cell line derived from adult foreskin. The FS2-3 adult foreskin cell culture was prepared by scraping the mucosal layer of an adult foreskin (obtained from an elective circumcision) into phosphate-buffered saline (PBS). The mucosal cells were collected by centrifugation at $500 \mathrm{~g}$ and then trypsinised for approximately $10 \mathrm{~min}$. The resulting cell suspension was washed with RPMI medium containing penicillin $2 \times 10^{6} \mathrm{IU} / \mathrm{L}$ and streptomycin $2000 \mathrm{mg} / \mathrm{L}$ and then seeded into $25-\mathrm{cm}^{3}$ tissue-culture flasks containing $5 \mathrm{ml}$ of RPMI culture medium. The resulting cell culture consisted mainly of fibroblasts. All experiments were performed on cultures between passage numbers 5 and 15 .

The cell cultures were maintained as frozen stocks at $-150^{\circ} \mathrm{C}$ in cell-culture media containing fetal bovine serum $20 \% \mathrm{v} / \mathrm{v}$ and dimethyl sulphoxide $10 \% \mathrm{v} / \mathrm{v}$ (DMSO). The cell lines were passaged in RPMI medium consisting of: RPMI (1640) base (Gibco) supplemented with $0.4 \mathrm{~mm}$ L-glutamine, $0.2 \mathrm{mM}$ sodium pyruvate, fetal bovine serum (Gibco) $10 \% \mathrm{v} / \mathrm{v}$, penicillin $1 \times 10^{6} \mathrm{IU} / \mathrm{L}$ and streptomycin $1000 \mathrm{mg} / \mathrm{L}$. Cell cultures were incubated at $37^{\circ} \mathrm{C}$ in $\mathrm{CO}_{2} 5 \%$ :air $95 \%$ in a water-saturated incubator. The $96-$ well trays used for experiments were seeded with $3 \times 10^{4}$ eukaryotic cells/well in antibiotic-free RPMI medium. For tests of the survival of bacteria in broth medium, Mueller-Hinton Broth supplemented with Isovitalex (MHI; Becton Dickinson and Co., Cockeysville, MD, USA) was used.

\section{Quantitation of $H$. ducreyi}

At appropriate intervals, the supernatant medium was aspirated by pipette and the cell monolayer was scraped to suspend it in the tissue culture medium. The resulting cell suspension was sonicated for $c .5 \mathrm{~s}$, and then pipetted with an Eppendorf micropipette to disperse the cells. Examination by light microscopy revealed that the eukaryotic cells were adequately dispersed by this procedure. The resultant suspension was diluted serially in 10-fold steps in tissue culture medium and $H$. ducreyi cfus were counted by the spread-plate method on chocolate agar.

\section{Transmission electronmicroscopy (TEM)}

FS2-3 cells were seeded on to Metricell GN-6 membrane filters (Gelman Sciences Inc., Ann Arbor, MI, USA) in 24-well trays at a concentration of $1 \times 10^{5}$ cells/well. The cells were incubated for 2 days and then infected with $H$. ducreyi at a multiplicity of infection (MOI) of approximately 10:1. After incubation for 2 days at $37^{\circ} \mathrm{C}$, the monolayers grown on the filters were pre-fixed by addition of glutaraldehyde (Eastman Kodak Co., Toronto, Ontario, Canada) to the tissue culture medium to a final concentration of $2 \% \mathrm{v} / \mathrm{v}$. The monolayers were fixed overnight and then given three 5-min washes in $0.1 \mathrm{M}$ sodium cacodylate, $0.01 \mathrm{M}$ calcium chloride (Fisher Scientific Co., Fairlawn, NJ, USA) pH 7.4 (rinse buffer). Freshly prepared osmium tetroxide (Polyscience Inc., Warrington, PA, USA) $1 \% \mathrm{w} / \mathrm{v}$ in rinse buffer was used to post-fix the monolayer by incubation at $4^{\circ} \mathrm{C}$ for $30 \mathrm{~min}$. The monolayer was washed three times, each for $5 \mathrm{~min}$ with rinse buffer. To increase the rigidity of the membranes, the monolayer was overlaid with agarose $3 \% \mathrm{v} / \mathrm{v}$ in rinse buffer.

The agarose-coated monolayer was processed by standard TEM procedures through graded series of acetone, propylene oxide (Polysciences Inc.) and JEM Bed 812 embedding medium (J.B. EM Services, Dorval, Quebec, Canada). Strips of the membrane were placed in embedding medium and polymerisation was achieved by incubating at $37^{\circ} \mathrm{C}$ overnight, then at $45^{\circ} \mathrm{C}$ for $10 \mathrm{~h}$, followed by $60^{\circ} \mathrm{C}$ for $18 \mathrm{~h}$. Thin sections were prepared and stained for $10 \mathrm{~min}$ with saturated uranyl acetate (Polysciences Inc.) $50 \% \mathrm{v} / \mathrm{v}$ in ethanol and post-stained for $5 \mathrm{~min}$ with lead citrate (Polaron Equipment Inc., Watford) $0.25 \%$ in $0.1 \mathrm{~N} \mathrm{NaOH}$. The sections were viewed with a Philips model 201 electronmicroscope, at an acceleration voltage of $60000 \mathrm{eV}$.

\section{Results}

To determine how well $H$. ducreyi survived in the cell cultures, compared with survival in broth medium alone, organisms were seeded into 96-well trays containing either $10^{4}$ eukaryotic cells/well or broth (RPMI or $\mathrm{MHI}$ ) only. At various times after infection, the number of viable organisms (cfu/ml) was assessed by the spread-plate technique. Each value recorded represented the mean of three replicate counts. $H$. ducrey $i$ died within 4 days when inoculated into $\mathrm{MHI}$ broth (fig. 1). Although survival was better (up to 12 days) in tissue culture medium containing FBS $10 \%, H$. ducreyi survived for extended periods (26 days) when growing with FS2-3 cells (fig. 1). The cell lines were infected separately with $H$. ducreyi strains 35000 , RO27, CIP542 and RO18, and $H$. influenzae type b and the infected monolayers were monitored by light microscopy to assess visible growth of the bacteria and any apparent cytopathic effect (CPE). On both FS2-3 and A549 cell culture, the $H$. ducreyi strains grew as branching fungal-like colonies, unlike $H$. influenzae type $b$ that grew as a uniform cell suspension with no apparent microcolony formation. The large complex microcolonies of $\boldsymbol{H}$. ducreyi (fig. 2) were observed only when eukaryotic cells were present. The microcolonies appeared to associate with or adhere preferentially to eukaryotic cells. When an MOI of 10:1 was used, a CPE was detected by day 3. This CPE was apparent with $H$. ducreyi strains RO18, RO27 and 35000 . Fig. 3 $(\mathrm{G}, \mathrm{H})$ shows the typical CPE on FS2-3 cells detected at days 3 and 7 after infection. There were no apparent differences; therefore, only the RO27-infected cell culture has been shown. On day 1, all infected monolayers were unaltered and were similar to the 

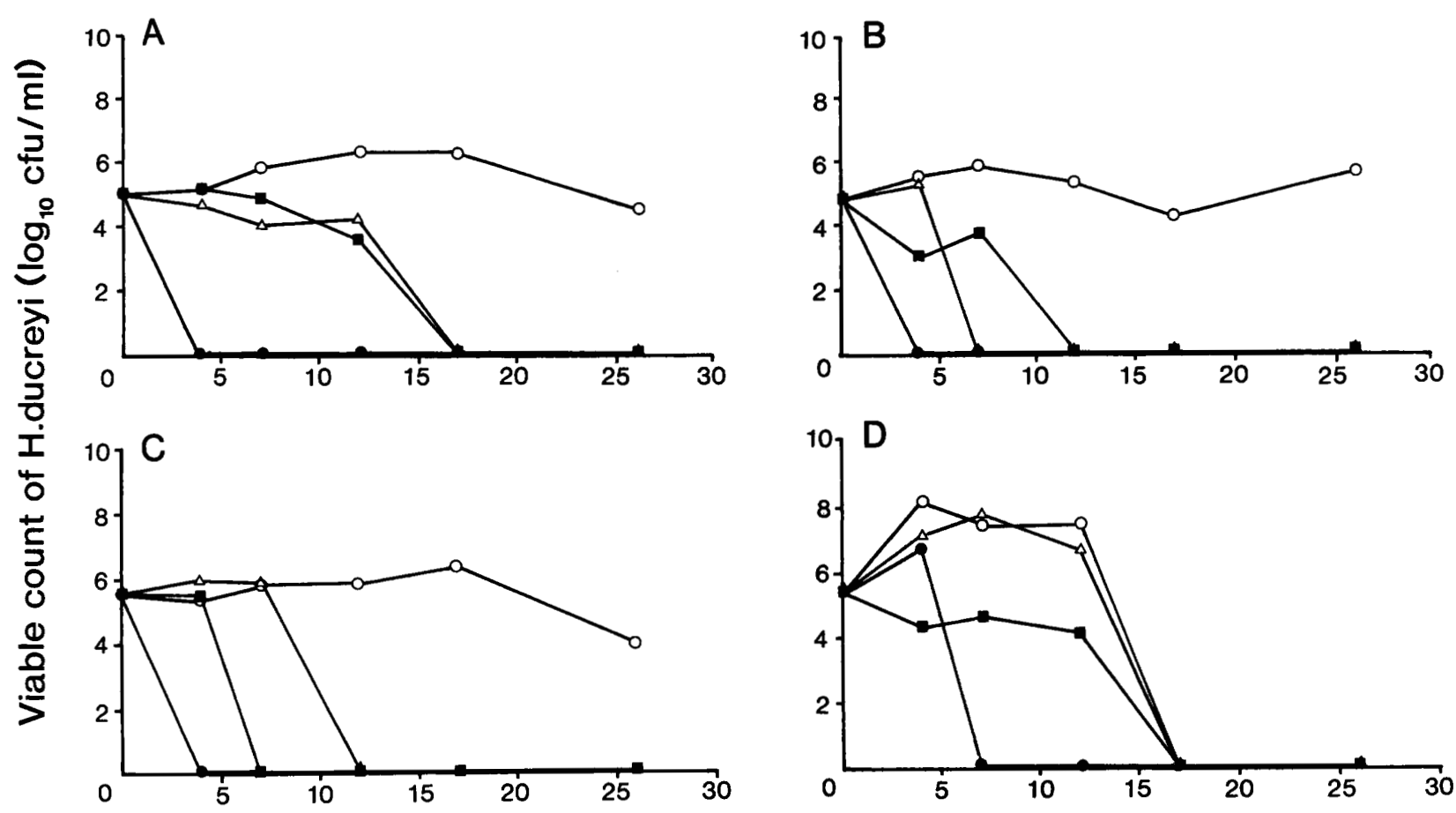

\section{Time (days)}

Fig. 1. Survival of Haemophilus spp. in cell culture and broth medium. Cell lines A549 ( $\triangle-$ ) and FS2-3 ( $-\mathrm{O}-$ ) were seeded $\left(3 \times 10^{4}\right.$ cells $/$ well $)$ in 96 -well trays and incubated at $37^{\circ} \mathrm{C}$ in $\mathrm{CO}_{2} 5 \%$ :air $95 \%$ for $24 \mathrm{~h}$. MHI $(-\infty)$ and tissue culture medium $(-\square-)$ was dispensed into wells with no eukaryotic cells. The monolayers and broths were inoculated with $H$. ducreyi CIP542 $1 \times 10^{5} \mathrm{cfu} / \mathrm{ml}(\mathbf{A})$, H. ducreyi $\mathrm{RO} 189 \times 10^{4} \mathrm{cfu} / \mathrm{ml}$, (B) H. ducreyi $350003 \times 10^{5} \mathrm{cfu} / \mathrm{ml}$ (C) and $H$. influenzae $3 \times 10^{5} \mathrm{cfu} / \mathrm{ml}(\mathbf{D})$. Samples were removed at the indicated times after infection and the numbers of viable Haemophilus cells were evaluated. Each point represents the average from triplicate tests.

uninfected controls. The CPE of $H$. ducreyi for adult foreskin cells was species-specific; inoculation of $H$. influenzae at the same MOI produced no detectable CPE on FS2-3 cells within the same time period (fig. 4C, D). The avirulent $H$. ducreyi CIP542 produced no detectable CPE on FS2-3 cells at days 3 or 7 after infection (fig. 3; E, F). If a higher inoculum was used to achieve an MOI of $500: 1, H$. ducreyi CIP542 could produce a weak CPE. Tissue specificity was also apparent, because the CPE produced by $H$. ducreyi isolates on A549 cells (fig. 4) was not as dramatic as that observed with FS2-3 cells (fig. 3), whereas $H$. influenzae produced no CPE on FS2-3 cells, but had a significant CPE on A549 cells.

Transmission electronmicroscopy (TEM) was used to determine whether $H$. ducreyi invaded the foreskin

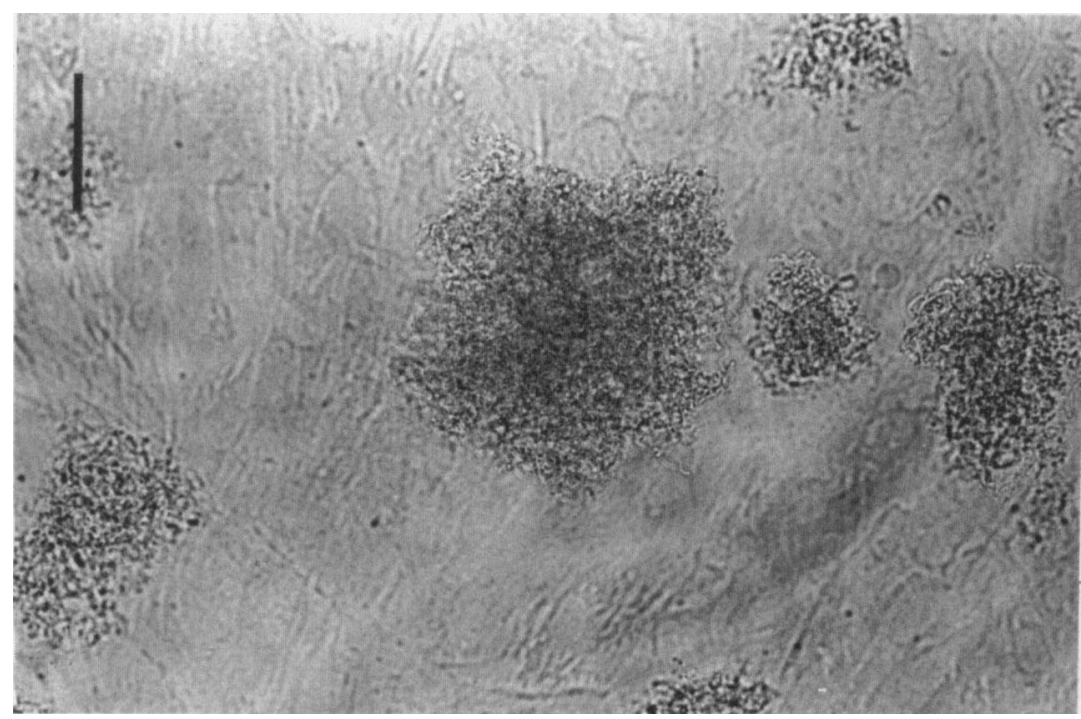

Fig. 2. Morphology of $H$. ducreyi microcolonies grown in foreskin cell culture. Flasks of FS2-3 cells were seeded with $H$. ducreyi RO18 $3 \times 10^{5} \mathrm{cfu} / \mathrm{ml}$. The flasks were incubated at $37^{\circ} \mathrm{C}$ in $\mathrm{CO}_{2} 5 \%$ : air $95 \%$ for $24 \mathrm{~h}$. The monolayers were viewed by light microscopy. Bar, $50 \mu \mathrm{m}$. 

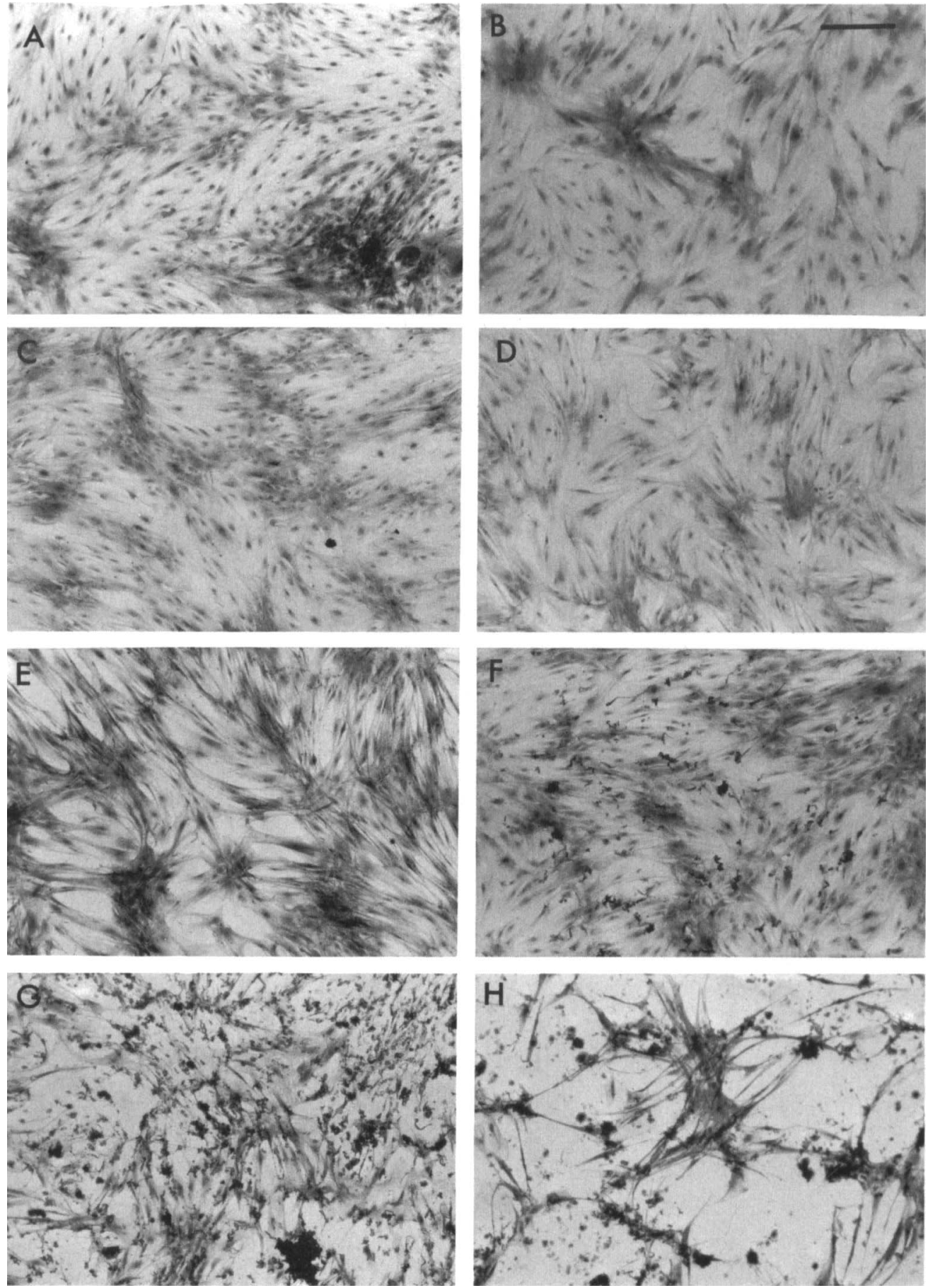

Fig. 3. Effect of $H$. influenzae and $H$. ducreyi on FS2-3 cells. Monolayers in 96-well tissue culture trays $\left(3 \times 10^{4}\right.$ cells/well) were uninfected (A, B) or infected with $H$. influenzae type b (C, D), H. ducreyi CIP542 (E, F) or H. ducreyi RO27 (G, H) at $3 \times 10^{5}$ bacterial/well. The monolayers were incubated at $37^{\circ} \mathrm{C}$ in $\mathrm{CO}_{2} 5 \%$ : air $95 \%$ for 3 days $(\mathbf{A}, \mathbf{C}, \mathbf{E}, \mathbf{G})$ or 7 days $(\mathbf{B}, \mathbf{D}, \mathbf{F}, \mathbf{H})$ and then stained with Coomassie Blue in methanol $20 \% \mathrm{v} / \mathrm{v}$, acetic acid $10 \% \mathrm{v} / \mathrm{v}$ for $15 \mathrm{~min}$. Excess stain was washed off and the monolayers were viewed by light microscopy. Bar, $100 \mu \mathrm{m}$.

cells in vitro. Two days after infection, $H$. ducreyi cells had not become intracellular, although there was pronounced intracellular vacuolisation (fig. 5). The microcolony formation noted by light microscopy proved to be closely associated with the cell membrane of FS2-3 cells (fig. 5). To ensure optimal structural integrity, the infected monolayers used for TEM were not washed before fixation. However, subsequent experiments with light microscopy confirmed that portions of the microcolonies remained attached to the eukaryotic cells despite extensive washing (results not shown). Intercellular adhesion of $H$. ducreyi as well as electron-dense areas in the cytoplasm were apparent (fig. 6). Close interaction of the $H$. ducreyi cell wall and the FS2-3 membrane indicate that attachment does occur (fig. 6). Indeed, the gap of 2-5 nm between the prokaryote and eukaryote membranes is similar to the gap between prokaryotic cells bound to one another (fig. 6).

To determine whether a soluble toxin was respon- 

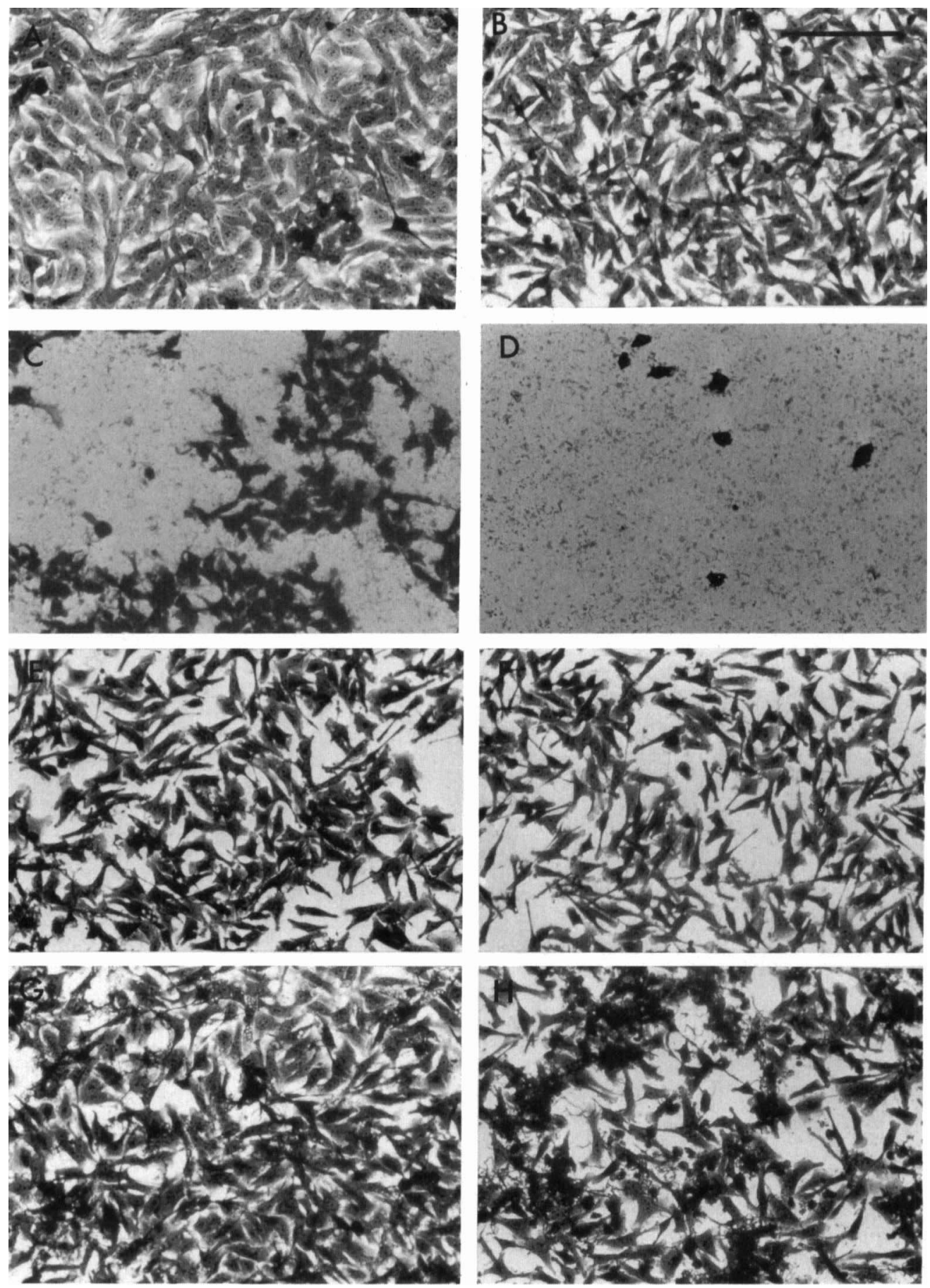

Fig. 4. Effect of $H$. influenzae and $H$. ducreyi on A549 cells. Monolayers in 96 -well tissue culture trays $\left(3 \times 10^{4}\right.$ cells/well) were uninfected (A, B) or inoculated with $H$. influenzae type b (C, D), H. ducreyi CIP542 (E, F) or $H$. ducreyi RO27 (G, H) at $3 \times 10^{5}$ bacteria/well. The monolayers were incubated at $37^{\circ} \mathrm{C}$ in $\mathrm{CO}_{2} 5 \%$ : air $95 \%$ for 3 days (A, C, E, G) or 7 days (B, D, F, H) and then stained with Coomassie Blue in methanol $20 \% \mathrm{v} / \mathrm{v}$, acetic acid $10 \% \mathrm{v} / \mathrm{v}$ for $15 \mathrm{~min}$. Excess stain was washed off and the monolayers were viewed by light microscopy. Bar, $50 \mu \mathrm{m}$.

sible for the CPE observed, a suspension of $H$. ducreyi RO27 was placed in a tissue-culture insert (Anocell, England) that allowed free diffusion of media, but had a pore size of $0 \cdot 2 \mu \mathrm{m}$, which prevented the bacteria from passing through to the cell-culture monolayer growing on the well beneath the insert. Even when a large inoculum of $H$. ducreyi $\mathrm{RO} 27\left(10^{8} /\right.$ well) was used, no CPE was detected for FS2-3 cells when the membrane insert, separating the bacteria from the monolayer, was present.

\section{Discussion}

The results of this study demonstrate that FS2-3 is a potentially valuable in-vitro cell-culture model for evaluating the interaction of $H$. ducreyi with eukaryotic cells. $H$. ducreyi strains survived for extended lengths of time only if eukaryotic cells were also present. Indeed, survival for at least 26 days after infection (fig. 1) (when the experiment was stopped) is far longer than the survival of 6 days noted in mice ${ }^{5,8}$ 

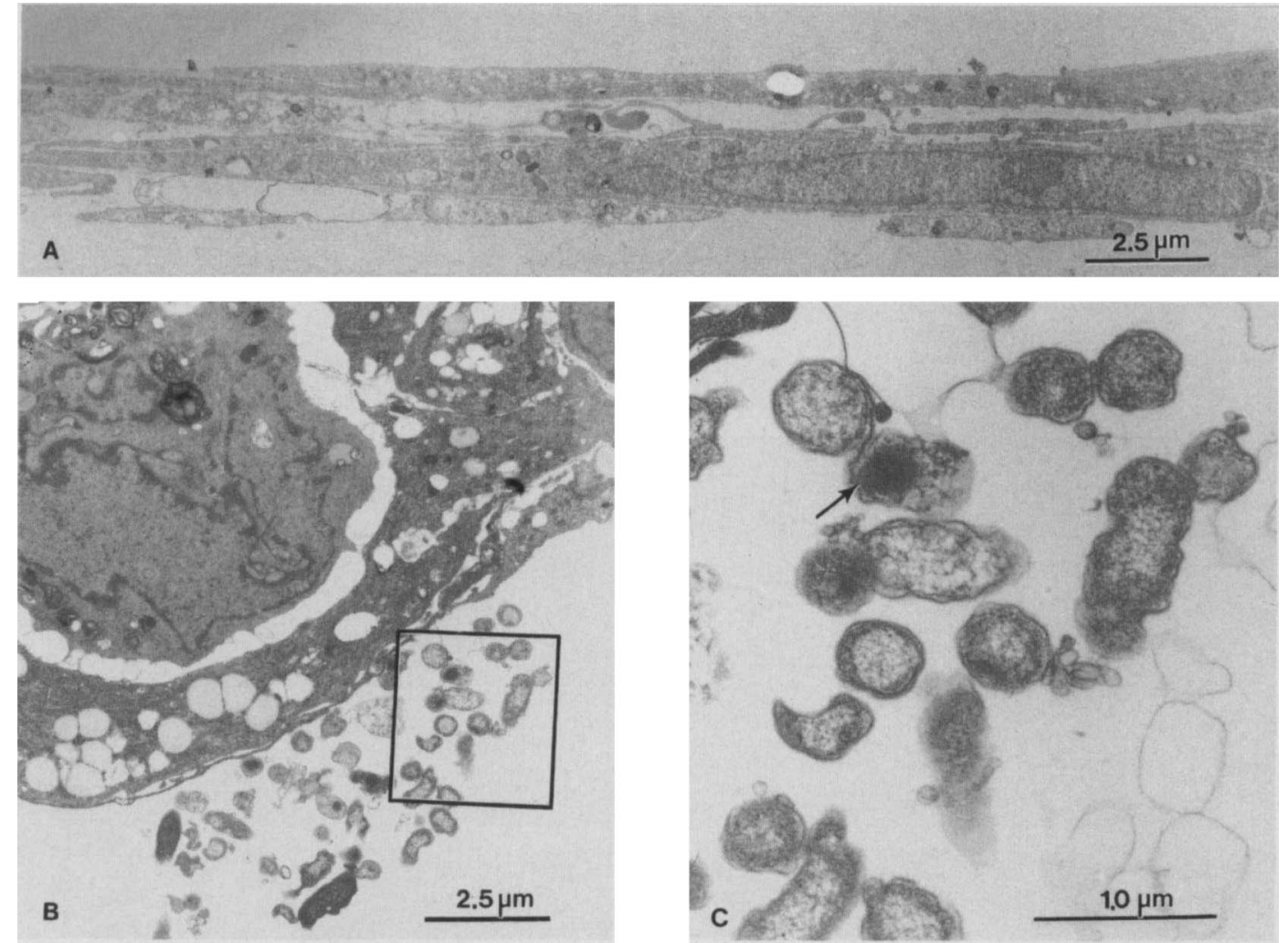

Fig. 5. Transmission electronmicroscopy of FS2-3 cells infected with $\boldsymbol{H}$. ducreyi. Monolayers of FS2-3 foreskin cells were grown on Metricell membranes. The monolayers were infected with $H$. ducreyi RO18 $5 \times 10^{5} /$ membrane (an MOI of 5:1). After incubation for $48 \mathrm{~h}$, the uninfected $(\mathbf{A})$ and infected $(\mathbf{B}, \mathbf{C})$ monolayers were fixed and then processed for transmission electronmicroscopy. The $H$. ducrey $i$ cells have intracellular electron-dense areas (small arrow).

or 72 hours in rabbits. ${ }^{3}$ This was to be expected, because there were no host-defence mechanisms present to eradicate the bacteria. In this respect, use of the foreskin-cell model would allow an assessment of cytotoxic effect independent of host factors. Although the viable counts of all three strains of $H$. ducreyi tested in the foreskin cell model (fig.l) indicated only minimal growth of organisms (approximately a 10-fold increase), in comparison with that of $H$. influenzae (approximately a $\log _{10} 3$ increase), this may represent an underestimation, because $H$. ducreyi grew as microcolonies (fig. 2) that were difficult to disperse into single-cell suspensions. Examination by light microscopy showed that the number and size of the microcolonies did increase with time. The microcolony formation is probably a result of cell-to-cell adhesion (figs. 5, 6), intercellular adherence of $H$. ducreyi cells having been described. ${ }^{9}$ It is possible that this type of growth, which has also been observed in vivo, represents a virulence factor that prevents phagocytosis by macrophages or polymorphonuclear cells, thereby allowing $H$. ducreyi to proliferate.

Preliminary experiments demonstrated that, despite extensive washing, portions of the $H$. ducreyi microcolonies remained attached to the monolayer (as assessed by light microscopy). Adherence of $H$. ducreyi to erythrocytes has been shown to correlate to hydrophobicity. ${ }^{10}$ The role of hydrophobic interactions was not assessed in our evaluation. The monolayers used for TEM were not extensively washed before fixation.
This was done to ensure structural integrity of the microcolonies. $H$. ducreyi cells that were closely associated with the FS2-3 membrane were apparent. However, since special stains such as ruthenium red were not used, it is not possible to determine whether the matrix observed between the FS2-3 membrane and the $H$. ducreyi cell wall (fig. 6) contains material that may be involved in binding. However, it is apparent that $H$. ducreyi was not internalised (fig. 5). This is consistent with histological analysis of chancroid ulcers, in which the organism has been observed only as extracellular clumps. ${ }^{6}$ This tissue interaction of $H$. ducreyi is distinct from that described by Roberts et $a l^{11}$ for $H$. influenzae. Evaluations with monkey respiratory tissue demonstrated that $H$. influenzae was rapidly (180 min after infection) internalised. ${ }^{11}$ Our TEM studies evaluated $H$. ducreyi internalisation at $48 \mathrm{~h}$ after infection; therefore, other intervals need to be evaluated to determine conclusively that internalisation does not occur.

The mechanism of ulcer formation in the mouse model has not been totally defined, but Tuffrey et al. ${ }^{7}$ demonstrated that viable organisms were not required and that lipopolysaccharide may be the crucial factor responsible for ulcer formation. $H$. ducreyi survives for long periods of time in man, but not in the current animal models. It is possible that there are factors that contribute to ulcer formation in man that cannot be detected in the mouse model because the organisms do not survive sufficiently long after intradermal injection 

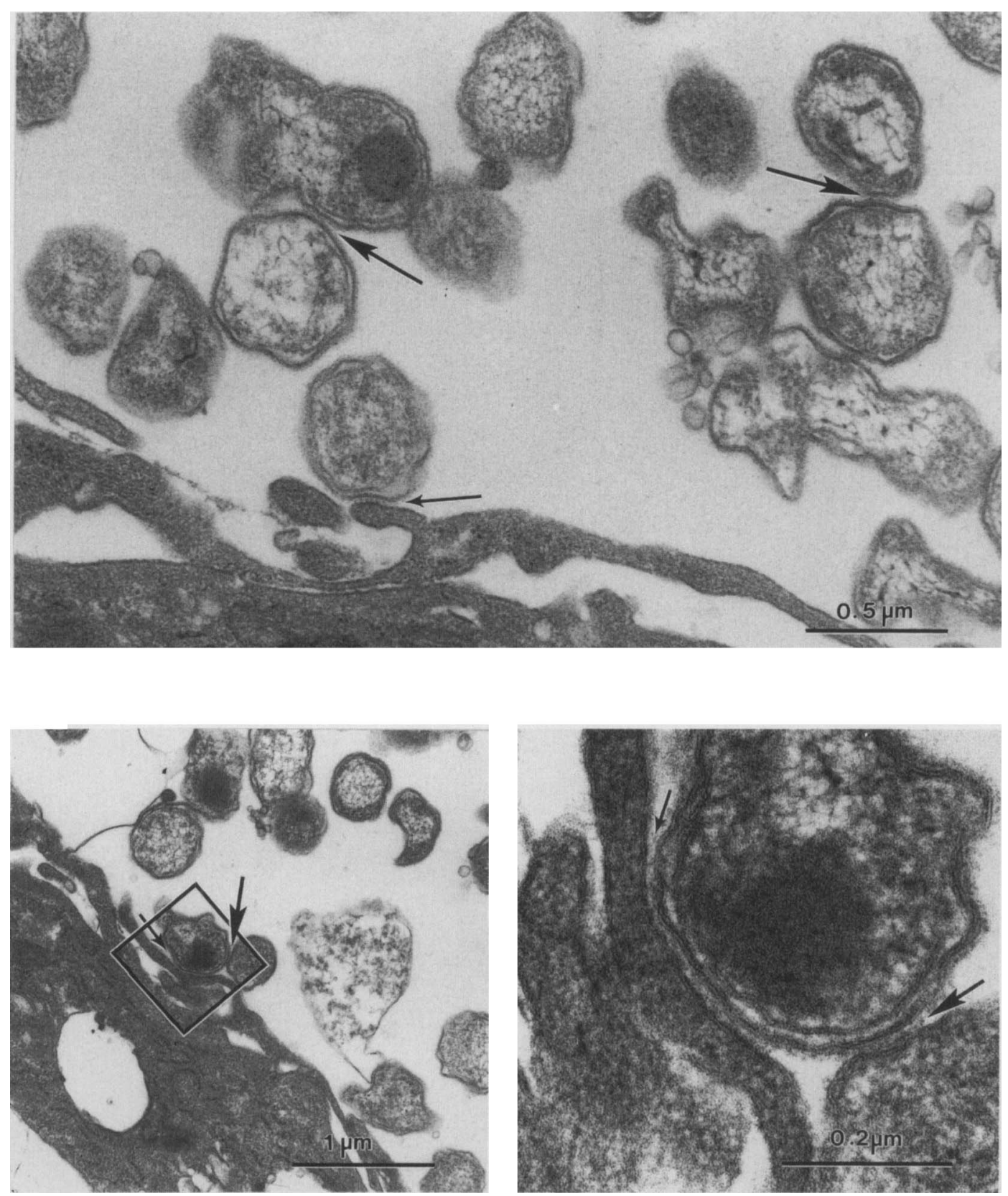

Fig. 6. Transmission electronmicroscopy of $H$. ducreyi RO18 cells grown in FS2-3 foreskin explant culture. Monolayers of FS2-3 foreskin cells were grown on Metricell membranes. H. ducreyi RO18 was inoculated at $5 \times 10^{5}$ bacteria/membrane (an MOI of $5: 1$ ). After incubation for $48 \mathrm{~h}$, the monolayers were fixed and then processed for transmission electronmicroscopy. The $H$. ducreyi cells have tight intercellular adhesion $(\rightarrow)$ as well as close association with the FS2-3 membrane $(\longrightarrow)$.

in mice. The human foreskin cell-culture model provides a method for assessing cytotoxicity in a more direct manner than do animal models. The results of this study show that the CPE produced by virulent $H$. ducreyi strains on FS2-3 cells required contact of the bacteria with eukaryotic cells and did not appear to be due to a diffusible toxin. How $H$. ducreyi caused the vacuolisation of FS2-3 remains to be elucidated. The factors responsible for the relative avirulence of $H$. ducreyi CIP542 are not known.

In summary, the FS2-3 foreskin cell culture model described in this paper provides an alternative to the animal models described previously. ${ }^{4,7}$ The greatest advantage of the FS2-3 in-vitro model was the distinct
CPE produced by virulent strains of $H$. ducreyi that was not apparent with either avirulent strains of $H$. ducreyi or other species such as $H$. influenzae or $H$. parainfluenzae. The foreskin cell culture model thus provides a means for studying the cytotoxicity of $H$. ducreyi, which in turn may help define the pathogenesis of chancroid.

This work was supported by a grant to M.J.A. from the St Boniface Research Foundation. I acknowledge the skilled technical assistance of P. Hazelton, Department of Medical Microbiology, University of Manitoba for the electronmicrographs presented in this paper. The human foreskin specimens were kindly supplied by Dr P. Jessamine. The skilled manuscript preparation of Joan Boughton is acknowledged. 


\section{References}

1. Albritton WL. Biology of Haemophilus ducreyi. Microbiol Rev 1989; 53: 377-389.

2. Reenstierna J. Experimental soft chancre in rabbits. Urol Cutan Rev 1921; 25: 332

3. Feiner RR, Mortara F. Infectivity of Haemophilus ducreyi for rabbit and development of skin hypersensitivity. $A m J$ Syph Gonor Ven Dis 1945; 29 : 71-79.

4. Hammond GW, Lian CJ, Wilt JC, Ronald AR. Antimicrobial susceptibility of Haemophilus ducreyi. Antimicrob Agents Chemother 1978; 13: 608-612.

5. Tuffrey M, Abeck D, Alexander F, Johnson AP, Ballard RC, Taylor-Robinson D. A mouse model of Haemophilus ducreyi infection (chancroid). FEMS Microbiol Lett 1988; 50: $207-209$.
6. Freinkel AL. Histological aspects of sexually transmitted genital lesions. Histopathology 1987; 11: 819-831.

7. Tuffrey M, Alexander F, Ballard RC, Taylor-Robinson D. Characterization of skin lesions in mice following intradermal inoculation of Haemophilus ducreyi. J Exp Pathol 1990; 71: 233-244.

8. Sturm AW, Stolting GJ, Cormane RH, Zanen HC. Clinical and microbiological evaluation of 46 episodes of genital ulceration. Genitourin Med 1987; 63: 98-101.

9. Morse SA. Chancroid and Haemophilus ducreyi. Clin Microbiol Rev 1989; 2: 137-157.

10. Abeck D, Korting HC, Wagner R, Ballard RC. Haemagglutinating properties of Haemophilus ducreyi. Lett Appl Microbiol 1990; 11: 45-47.

11. Roberts M, Jacobs, RF, Haas JE, Smith AL. Adherence of Haemophilus influenzae to monkey respiratory tissue in organ culture. J Gen Microbiol 1984; 130: 1437-1447. 